\title{
LEVEL OF ANXIETY OF PREGNANT MOTHER IN FACING SECTIO CAESAREA OPERATIONS IN DKT SIDOARJO HOSPITAL
}

\author{
Marlita Dewi Lestari', Kusuma Wijaya Ridi Putra ${ }^{1 *}$, Dimyati \\ ${ }^{1}$ Kerta Cendekia Nursing Academy, Lingkar Timur Road, Rangkah Kidul, Sidoarjo, 61234 \\ ${ }^{2}$ DKT Sidoarjo Hospital, Dr. Soetomo Road No. 2, Sidoarjo
}

\author{
*Correspondence: \\ Kusuma Wijaya Ridi Putra \\ Email: ridiputra@hotmail.com
}

\begin{abstract}
Background: Mothers who undergo labor with Sectio Caesarea operation can experience anxiety because they have never experienced surgery or do not know about the actions to be taken.

Objectives: The study aimed to determine the maternal anxiety level of preoperative sectio caesarea in the Maternity Room of the DKT Hospital in Sidoarjo.

Methods: The research design used was descriptive method with cross sectional approach. The population in this study were patients who will undergo labor with sectio caesarea in the Maternity Room of the DKT Hospital in Sidoarjo. Sampling technique with accidental sampling. The instrument used was the Hamilton Rating Scale for Anxiety (HRS-A) which was adopted from the book Stress, Anxiety, and Depression Management (Hawari, 2004), which included 14 psychological symptoms of anxiety.

Results: The results showed that the most anxiety level of preoperative sectio caesarean mothers was moderate anxiety as many as 25 people $(50 \%)$.

Conclusion: The anxiety level of mothers who will undergo Caesarean section surgery is moderate anxiety, so special care is needed by health workers. Handling that can be given in the form of health education about surgical procedures and post-surgical treatment. In addition, providing knowledge to the family so that they will continue to motivate mothers who will face the caesarean section surgery.
\end{abstract}

Key words: Level of anxiety, caesarean section surgery, labor.

\section{INTRODUCTION}

Sectio caesarea is an artificial labor, in which the fetus is born through an incision in the abdominal wall and uterine wall with a uterine incision intact and the fetus weighs above 500 grams (Sarwono, 2005). Sectio caesarea is a surgical procedure for the birth of a fetus with an incision through the abdomen and uterus (Liu, 2007). The action of sectio caesarea is done if it is not possible to do pervaginal labor due to the risk of the mother or fetus, with consideration of things that need sectio caesarea actions such as the normal delivery process or failure of the normal labor process (Saifudin, 2002). The incidence of sectio caesarea in the world in 2010 based on WHO reached $10 \%$ to $15 \%$ of all labor processes. In developed countries the caesarean section delivery rate reached $15 \%$ from the previous $5 \%$ in 2010. Whereas in developing countries 
such as Canada the caesarean section number reached $21 \%$ of all deliveries (Husna, 2012). In Indonesia the delivery of the sectio caesarea method is not new anymore. This is evidenced by the increasing number of caesarean sections in the last 20 years in Indonesia from 5\% to $20 \%$ in 2010 (Depkes RI, 2012). Based on data from the Medical Record of the DKT Hospital in Sidoarjo in January 2017 December 2017 the number of operations was 1,959 of them who underwent caesarean section as many as 1272 patients $(65 \%)$

Anxiety is an emotional and subjective experience of someone. This emotional state is usually a subjective individual experience, not specifically known for the cause (Hawari, 2008). Anxiety when a person is going to undergo Sectio caesarea surgery if not managed properly can be increasingly complicated which can harm and endanger the patient himself, because it can cause difficulties in the process of surgery, endanger the safety of patients and also increase the costs to be borne by the patient and his family. Because it's our job, health workers must be able to help so that patients who will undergo Sectio caesarea surgery so that their anxiety can be controlled, decreased and not worry if possible, so that patients feel comfortable.

\section{METHODS}

Study Design

In this research, the design used was descriptive design for describing the mother's anxiety preoperative sectio caesarea at the Maternity Room in DKT Hospital Sidoarjo.

Setting

The study was conducted from February 26, 2018 to March 28, 2018, in the Maternity Room of the DKT Hospital in Sidoarjo, Jalan Dr. Soetomo No. 2 Sidoarjo. section at the Maternity Room in the DKT Hospital Sidoarjo 50 people in March 2018. This study uses a type of accidental sampling technique, namely sampling method based on chance (Sugiyono, 2008) in the sense patients who will undergo labor with caesarean section at the Maternity Room in DKT Hospital Sidoarjo. The sample used in this study were all patients who will undergo labor with sectio caesarean surgery the first time in the Maternity Room of DKT Hospital Sidoarjo.

\section{Instruments}

The instrument used was the Hamilton Rating Scale for Anxiety (HRS-A) adopted from the book Stress, Anxiety, and Depression Management (Hawari, 2004), which included 14 psychological symptoms of anxiety, namely anxiety, tension, fear, disturbance sleep, feelings of depression (moody), somatic/ physical (muscle) symptoms, somatic/ physical (sensory) symptoms, cardiovascular symptoms (heart and blood vessels), respiratory symptoms (breathing), gastrointestinal symptoms (digestion), urogenital symptoms (urinary and genitalia), autonomic symptoms, and behavior (attitude) in the interview. This tool consists of 14 groups of symptoms which each group is detailed again with more specific symptoms. Each symptom group is given a score (score) between 0-4, which means: $0=$ no symptoms (complaints) anxiety; $1=$ mild anxiety symptoms; $2=$ moderate anxiety symptoms; 3 = symptoms of severe anxiety; and $4=$ symptoms of severe anxiety.

\section{Data Analysis}

Based on the results of the assessment in the questionnaire, the level of anxiety can be categorized as follows: Score <14: No anxiety; score 14-20: Mild anxiety; score 21-27: Moderate anxiety; score 28-41: Severe anxiety; and score 42-56: Panic.

\section{Research Subject}

In this study, the population is patients who will undergo labor with caesarean 


\section{Ethical Consideration}

This research has obtained permission from the head of the DKT Hospital in Sidoarjo and also obtained permission from National Unity and Politics of Sidoarjo Regency.

\section{RESULTS}

Characteristic of Respondents by Level of Anxiety

Table 1. Distribution of Respondents by Level of Anxiety in the DKT Sidoarjo Hospital on March, $2018(n=50)$.

\begin{tabular}{ccc}
\hline Level of Anxiety & Frequency & Percentage (\%) \\
\hline No Anxiety & 0 & 0 \\
Mild & 0 & 0 \\
Moderate & 25 & 50 \\
Severe & 17 & 34 \\
Panic & 8 & 16 \\
\hline Total & 50 & 100
\end{tabular}

Sources: Primary Data of Questionnaire, 2018

Based on the results of the research data in the table above, it found that the majority of respondents had moderate anxiety while facing caesarean section surgery as many as 25 respondents $(50 \%)$ and a small proportion of respondents in panic conditions as many as 8 respondents $(16 \%)$.

\section{DISCUSSION}

The results of the research on the Anxiety Level of Preoperative Sectio Caesarea in the Maternity Room of the DKT Sidoarjo Hospital in March 2018 found that most respondents experienced moderate anxiety in the face of caesarean section surgery as many as 25 respondents $(50 \%)$ and a small proportion of respondents in panic conditions as many as 8 respondents (16\%). This condition can be caused by several factors, including age, level of education, work, and readiness in undergoing the caesarean section operation process. older age can control feelings of anxiety that are not excessive. Age increase is usually also followed by mental development for the better and the process of overcoming anxiety is getting better so that the more mature the age level also decreases the level of anxiety. Viewed from the cognitive aspects of human development, cognitive development is a genetic process that is a process based on the biological mechanism of the development of the nervous system. With the increasing age of a person, the more complex the composition of nerve cells and the more their ability to overcome anxiety is getting better so that the more mature the age of a person the lower the level of anxiety. According to Hurlock (2009), the more age, the level of maturity and strength of a person will be more mature in thinking and responding to the problem at hand. This is a result of experience and maturity of his soul. Education also affects a person's knowledge and level of knowledge affects the mindset of the problems/ stress faced manifested by anxiety. Because people who have higher education indirectly, they get more information in everything including the mechanism to deal with stress. According to Notoatmodjo (2010), information obtained from both formal and non-formal education can provide a shortterm effect resulting in changes or increased knowledge. Employment (working as a private employee / civil servant) also affects one's knowledge. Someone who works outside the home will meet and mingle with more people in the workplace so that there are more opportunities to receive and discuss information that is being discussed or needed. Information can affect a person's level of knowledge. The better a person's knowledge, the lower the level of anxiety faced. According to Dervin (2010), the situation and conditions around someone will cause the emergence of information needs where the information needs are in accordance with the context in which the person is located. A person's readiness in undergoing the operation process section 
caesarea is very instrumental in increasing the person's anxiety in facing the section caesarea operation. This is due to lack of mental preparation, lack of information, knowledge, and lack of financial readiness compared to those that indicate elective surgery, people who are not or not ready to face challenges will have higher levels of anxiety. A person's anxious response depends on personal readiness, understanding in facing challenges, selfesteem, and coping mechanisms used as well as self-defense mechanisms used to overcome his anxiety, among others by suppressing conflict, impulses that cannot be consciously accepted, do not want to think things that are less pleasing to him (Stuart, 2007).

\section{CONCLUSION}

The anxiety level of mothers who will undergo Caesarean section surgery is moderate anxiety, so special care is needed by health workers.

\section{SUGGESTIONS}

Handling that can be given in the form of health education about surgical procedures and post-surgical treatment. In addition, providing knowledge to the family so that they will continue to motivate mothers who will face the caesarean section surgery.

\section{REFERENCES}

Depkes, RI. (2012). Buku Acuan Persalinan Normal. Jakarta: DepKes RI.

Dewi, Yusmiati. (2007). Manajemen Stres, Cemas: Pengantar Dari A Sampai Z. Jakarta: Edsa Mahkota.

Hawari. D. (2008). Manajemen Cemas dan Depresi. Jakarta: Balai Penerbit Fakultas Kedokteran Universitas Indonesia.

Kartono, K. (2006). Perilaku Manusia, Pengantar Singkat tentang Psikologi. Bandung: Rafika Aditama.
Kasdu, Dini. (2008). Solusi Problem Persalinan. Jakarta: Puspa Swara.

Liu, David. (2007). Manual Persalinan. Jakarta: EGC.

Nolan. M. (2008). Kehamilan dan Melahirkan. Jakarta: Arcan.

Notoatmodjo, S. (2010). Metode Penelitian Kesehatan. Jakarta: Rineka Cipta.

Nursalam. (2009). Konsep dan Penerapan Metodologi Penelitian Ilmu Keperawatan. Jakarta: Salemba Medika.

Nurkasana. (2014). Hubungan antara Terapeutik dengan Tingkat Kecemasan pada Pasien PraOperasi Sectio Caesarea di Ruang Ponek RSUD Karanganyar. Skripsi (Tidak dipublikasikan). Surakarta: STIKes Kusumahusada.

Pawatte, Inggriet, Cicilia Pali, Henry Opod. (2013). Perbedaan Tingkat Kecemasan pada Ibu Pre Seksio Caesarea di RSIA Kasih Ibu dan RSUP. Prof. Dr. R.D. Kandou Manado. Jurnal Kedokteran Komunitas dan Tropik, Volume 1 Nomor 3 Agustus 2013.

Prawirohardjo. S. (2008). Ilmu Kebidanan. Jakarta: Yayasan Bina Pustaka Sarwono.

Qulsum dkk. (2012). Perbedaan Tingkat Kecemasan Pada Pasien Pre Operasi Sebelum dan Sesudah Pemberian Terapi Musik Klasik di RSUD Tugurejo Semarang, http://ejournal.stikestelogorejo.ac.id.

Satria, A. (2008). Kamus Besar Bahasa Indonesia. Jakarta: Halim Jaya.

Setiadi. (2007). Konsep dan Penulisan Riset Keperawatan. Yogyakarta Graha Ilmu.

Sjahriati. (2009). Beberapa Konsep tentang Anxiety dalam Anxiety Pendekatan Klinik Biokimia dan Farmakologi. Yayasan Darma Husada. Jakarta.

Stuart, G.W. (2007). Buku Saku Keperawatan Jiwa. edisi 5. Jakarta: EGC. 
Stoppord, M. (2011). Panduan Mempersiapkan Kehamilan dan Kelahiran. Yogyakarta: Pustaka Pelajar.

Suhartatik. (2014). Faktor-faktor yang Mempengaruhi Ibu Hamil di Dalam Memilih Persalinan Sectio Caesarea di Rumah Sakit Ibu dan Anak Pertiwi Makasar. Jurnal Keperawatan. Volume 4 Nomor 3 Tahun 2014.

Sudiyanto. A. (2010). Aspek Klinik Gangguan Anxietas. Disampaikan pada National Awarness Anxiety Program di Surakarta.

Sugiyono. (2008). Metode Penelitian Kuantitatif, Kualitatif, $R \quad \& \quad D$. Bandung: Alfabeta.

Suharsimi, Arikunto. (2006). Prosedur Penelitian Suatu Tinjauan Praktek. Jakarta: Rineka Cipta.

Sundari, Siti. (2005). Kesehatan Mental Dalam Kehidupan. Jakarta: PT Asdi Mahasatya.

Sukanto. (2005). Sosiologi Suatu Pengantar. Jakarta: Rajagrafindo.

Suliswati. (2006). Konsep Dasar Keperawatan Kesehatan Jiwa. Jakarta: EGC.

Supriyadi, A. (2009). Hipertensi dalam kehamilan. Kartini. Jakarta: PT Kartini Cahaya Lestari.

Suririnah. (2008). Buku Pintar Kehamilan dan Persalinan. Jakarta: PT. Gramedia Pustaka Utama.

Tobing, Lumban. (2008). Tekanan Darah Tinggi. Jakarta: FKUI.

Wawan dan Dewi. (2010). Teori Pengukuran Pengetahuan, Sikap dan Perilaku Manusia. Jogjakarta: Nuha Medika.

Wibisono. (2004). Teori Kecemasan. Jakarta: Buku Kedokteran EGC.
Cite This Article As: Lestari, M.D., Putra, K.W.R., Dimyati. Level of Anxiety of Pregnant Mother in Facing Sectio Caesarea Operations in DKT Sidoarjo Hospital. Nurse and Health: Jurnal Keperawatan 2019; 8(1): 23-27. 